\title{
DNA analysis of cattle parasitic protozoan Tritrichomonas foetus after photodynamic therapy
}

\author{
A. Margraf-Ferreira ${ }^{a}$, I.C.S. Carvalho ${ }^{b}$, S.M. Machado ${ }^{a}$, C. Pacheco-Soares ${ }^{a}$, C.W. Galvão ${ }^{c}$, \\ R.M. Etto ${ }^{\mathrm{d}}$, N.S. da Silva ${ }^{\mathrm{a}, *}$ \\ a Research and Development Institute, UNIVAP, São José dos Campos, SP 12244-000, Brazil \\ b Biosciences and Oral Diagnosis Department, ICT/UNESP, São José dos Campos, SP, Brazil \\ c Structural, Molecular and Genetics Biology Department, UEPG, Ponta Grossa, PR, Brazil \\ d Chemistry Department, UEPG, Ponta Grossa, PR, Brazil
}

\section{A R T I C L E I N F O}

\section{Article history:}

Received 22 September 2016

Received in revised form 16 February 2017

Accepted 21 February 2017

Available online 24 February 2017

\section{Keywords:}

Cell death

$\mathrm{AlPcS}_{4}$

DNA damage

Comet assay

\begin{abstract}
A B S T R A C T
Photodynamic therapy (PDT) is a modality of therapy that involves the activation of photosensitive substances and the generation of cytotoxic oxygen species and free radicals to promote the selective destruction of target tissues. This study analyzed the application of PDT to Tritrichomonas foetus, a scourged and etiological agent of bovine trichomoniasis, a sexually transmitted infectious disease. As it is an amitochondrial and aerotolerant protozoan, it produces energy under low $\mathrm{O}_{2}$ tension via hydrogenosome. $T$. foetus from an axenic culture was incubated with photosensitizer tetrasulfonated aluminium phthalocyanine and then irradiated with a laser source (InGaAIP) at a density of $4.5 \mathrm{~J} \mathrm{~cm}^{-2}$. The DNA integrity of the control and treated group parasites was analyzed by conventional gel electrophoresis and comet assay techniques. In previous results, morphological changes characterized by apoptotic cell death were observed after $T$. foetus was submitted to PDT treatment. In the treated groups, $T$. foetus DNA showed a higher concentration of small fragments, about $200 \mathrm{pb}$, in gel electrophoresis after PDT. In the comet assay, the DNA tail percentage was significantly higher in the treated groups. These results demonstrate that PDT leads to DNA fragmentation with changes in nuclear morphology and apoptotic features.
\end{abstract}

(C) 2017 Elsevier B.V. All rights reserved.

\section{Introduction}

Bovine trichomoniasis is a sexually transmitted disease caused by flagellate protozoan Tritrichomonas foetus, resulting in infertility, vaginitis, endometritis, abortion and sometimes pyometra in cows [1], and, therefore, considerable economic loss, all over the world.

Photodynamic therapy (PDT) is a modality of therapy used to treat various types of malignant or non-malignant neoplasic diseases [2], although its therapeutic potential is evident with regard to other diseases of muco-cutaneous manifestations resistant to antibiotic treatments [3]. PDT associated with phthalocyanines proved to be efficient in inactivation of parasites [4]. Its principle involves the activation of photosensitive substances by a light source and the generation of cytotoxic reactive oxygen species (ROS) and free radicals that cause selective destruction of target tissues [5]. The photodynamic reaction exemplifies the non-thermal

\footnotetext{
* Corresponding author.

E-mail address: nsoares@univap.br (N.S. da Silva).
}

effects of non-ionizing interaction between visible light of specific wavelength and a photosensitizing agent to initiate cytotoxic species that causes an oxidative cascade of events that result in cell death either by apoptosis or necrosis [6,7]. The cell response to PDT depends on the parameters used [8-10]. The cell death process is part of the mechanism of control of the number of cells acting as a mechanism of defence by removing undesired cells, including those potentially dangerous to the body, as well as of prevention of various diseases [11-14].

Studies have shown the existence of Programmed Cell Death (PCD) in unicellular organisms [15-22] and postulated a functional role of PCD in their biology. However, very little is known about the molecular mechanisms by which PCD occurs in these organisms [23]. The study of the cell death mode of $T$. foetus is compelling not just because of its unicellular nature, but also because it does not have mitochondria. Energy production under low oxygen tension in $T$. foetus occurs via an unusual anaerobic membrane-bound organelle called hydrogenosome [24-27].

Many ultrastructural changes indicate the type of cell death pathway activity in $T$. foetus, such as nuclear fragmentation, 
degradation of cytoplasmatic components, hydrogenosome shape changes, plasmatic membrane projections (blebs), flagellar internalization, release of lysosomal enzyme, cell shape changes, cytoplasm vacuolization, photosensitizing(PS) externalization, and caspase activation [4,25,28-35]. In the present study, $T$. foetus treated with PDT associated with photosensitizer tetrasulfonated aluminium phthalocyanine $\left(\mathrm{AlPcS}_{4}\right)$ showed "ladder-patterned" DNA fragments, in conventional electrophoresis assay and longer tails in Comet Assay. The DNA fragmentation detected in both assays indicates that $T$. foetus suffered apoptosis after PDT treatment. Thus, it can be affirmed that PDT treatment is effective in combating $T$ foetus, since it induces cell death by DNA fragmentation.

\section{Material and methods}

\subsection{T. foetus maintenance and PDT}

A T. foetus K strain was kindly provided by Dr. Fernando Costa e Silva Filho from Norte Fluminense State University (UENF/RJ/Brazil) and by Dr. Marlene Benchimol from Santa Ursula University (USU/RJ/Brazil). The parasites were maintained in TYM medium (Dyamond, 1957) supplemented with $10 \%$ foetal bovine serum at pH 6.8 and $37{ }^{\circ} \mathrm{C}$ in $5 \% \mathrm{CO}_{2}$ atmosphere and subcultured every $48 \mathrm{~h}$. Tetrasulfonated aluminium phthalocyanine (AlPcS4) (Porphyrin Products, INC.) was dissolved in phosphate buffered saline (PBS; $10 \mathrm{mM}$ phosphate buffer at $\mathrm{pH} 7.2$ containing $0.15 \mathrm{M} \mathrm{NaCl}$ ) and stored at $4{ }^{\circ} \mathrm{C}$. For the experiments, the PS colorant was diluted to $10 \mu \mathrm{M}$ and its absorption spectra were read in a spectrophotometer (UV-VIS Varian Cary 50). The parasite cells $\left(1 \times 10^{6}\right)$ were incubated with either $\mathrm{AlPcS}_{4}(10 \mu \mathrm{M})$ diluted in PBS or the same volume of PBS (control) for $60 \mathrm{~min}$. in the dark at $37^{\circ} \mathrm{C}$ in a $5 \%$ $\mathrm{CO}_{2}$ atmosphere. After this period, the cells were centrifuged at $850 \times \mathrm{g}$ for $10 \mathrm{~min}$ at $4{ }^{\circ} \mathrm{C}$, and then washed with PBS twice in order to remove any photosensitizer not absorbed by cells. Next, $500 \mu \mathrm{L}$ of fresh TYM medium supplemented with $10 \%$ foetal bovine serum was added to each tube and the whole content was transferred to wells (area $=1.8 \mathrm{~cm}^{2}$ ) on 24-well plates. The plates were irradiated with a semiconductor laser (Thera Laser - DMC), with active medium InGaAIP $\left(\lambda=685 \mathrm{~nm} ; \mathrm{P}=26 \mathrm{~mW} ; \mathrm{D} . \mathrm{E}=4.5 \mathrm{~J} / \mathrm{cm}^{2} ; \mathrm{t}=3.52 \mathrm{~s}\right)$ in the dark, after which the protozoan cells were reincubated at $37^{\circ} \mathrm{C}$ in $5 \% \mathrm{CO}_{2}$ atmosphere for $24 \mathrm{~h}$.

\subsection{DNA extraction and analysis}

About $1 \times 10^{6}$ of PDT-treated trophozoites and control cells were harvested and resuspended in $500 \mu \mathrm{L}$ DNA extraction buffer (10 mM Tris- $\mathrm{HCl}$ (pH 8.0); 25 mM EDTA (pH 8.0); $100 \mathrm{mM} \mathrm{NaCl}$ and $1 \%$ SDS). After cell disruption by the freeze-squeeze method, $250 \mu \mathrm{L}$ of phenol, chloroform and isoamyl alcohol (25:24:1) were added. The sample was homogenized and then centrifuged at $12000 \mathrm{xg}$ for $10 \mathrm{~min}$. After that, the supernatant was transferred to a new tube and the DNA was precipitated by addition of absolute isopropanol ( $1 \mathrm{vol}$ ) and incubation for $2 \mathrm{~h}$ at $-20^{\circ} \mathrm{C}$. Then, the samples were centrifuged at $12000 \times \mathrm{g}$ for $30 \mathrm{~min}$; the supernatant was discarded and $70 \%$ ethanol was added to the pellet followed by double centrifugation at $12000 \times \mathrm{g}$ for $30 \mathrm{~min}$. After ethanol removal, the tubes were allowed to dry at room temperature. The pellet was resuspended with deionized water, treated with RNAse A and then stored at $-20^{\circ} \mathrm{C}$ until use. The extracted DNA was quantified in NanoVue Plus Spectrophotometer (GE Healthcare) and visualized by conventional gel electrophoresis (CGE) in 1.5\% agarose. After staining with ethidium bromide, the DNA was visualized with Transiluminator UV Fusion FX (Vilber Loumart) and images were acquired with software FusionCapt Advanced FX5 (Vilber Loumart).

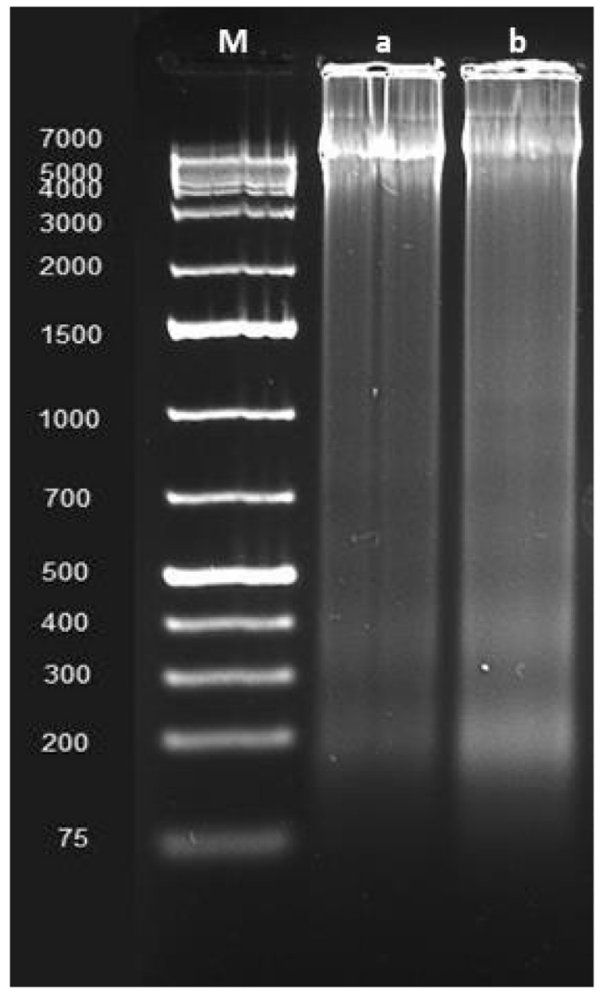

Fig. 1. Ladder pattern of Tritrichomonas foetus DNA extracted from non-treated (A) and treated cells (B) by Photodynamic Therapy. Conventional gel electrophoresis (agarose 1\%), stained with ethidium bromide. $\mathrm{M}-1 \mathrm{~kb}$ ladder (Thermo Science).

\subsection{Single cell gel electrophoresis/comet assay}

T. foetus parasites were cultivated as previously described and evaluated following the Single Cell Gel Electrophoresis/Comet Assay (SCGE/Comet Assay) protocol used by [36] and described by [37]. The number of control and PDT-treated cells was adjusted for $1 \times 10^{4}$. Images were acquired with an epifluorescence microscope (Leica Epifluorescence Microscope DMLB fitted with a Leica DFC310FX camera to capture pictures). Mean tail moments (tail length $\times$ tail DNA\%) were automatically scored using the OpenComet analysis software. Two-tailed Student $t$-tests were used for data statistical analysis and software Prism (GraphPad Software) for representation $[36,38,39]$.

\section{Results}

The effect of PDT on the DNA integrity of $T$. foetus was evaluated. Genomic DNA from PDT-treated and untreated cells was separated on agarose gel and the resulting bands were analyzed for size and intensity. PDT-treated cells presented a higher concentration of small DNA fragments, around $200 \mathrm{pb}$, and "ladder-patterned" DNA (Fig. 1), indicating that PDT induced DNA fragmentation, differently from that seen in the control group.

For a wider evaluation of the effect of PDT onto DNA fragmentation, the alkaline comet assay was performed. This technique evaluates DNA fragmentation through the extension of the comet tail at the level of individual cells [40]. The percentage of DNA in the comet tail in the PDT-treated group was significantly higher than in the control group ( $p=0.0051$ ) (Fig. 2).

The ladder pattern of discontinuous DNA fragments obtained in PDT-treated protozoa after CGE is a hallmark of apoptosis. 

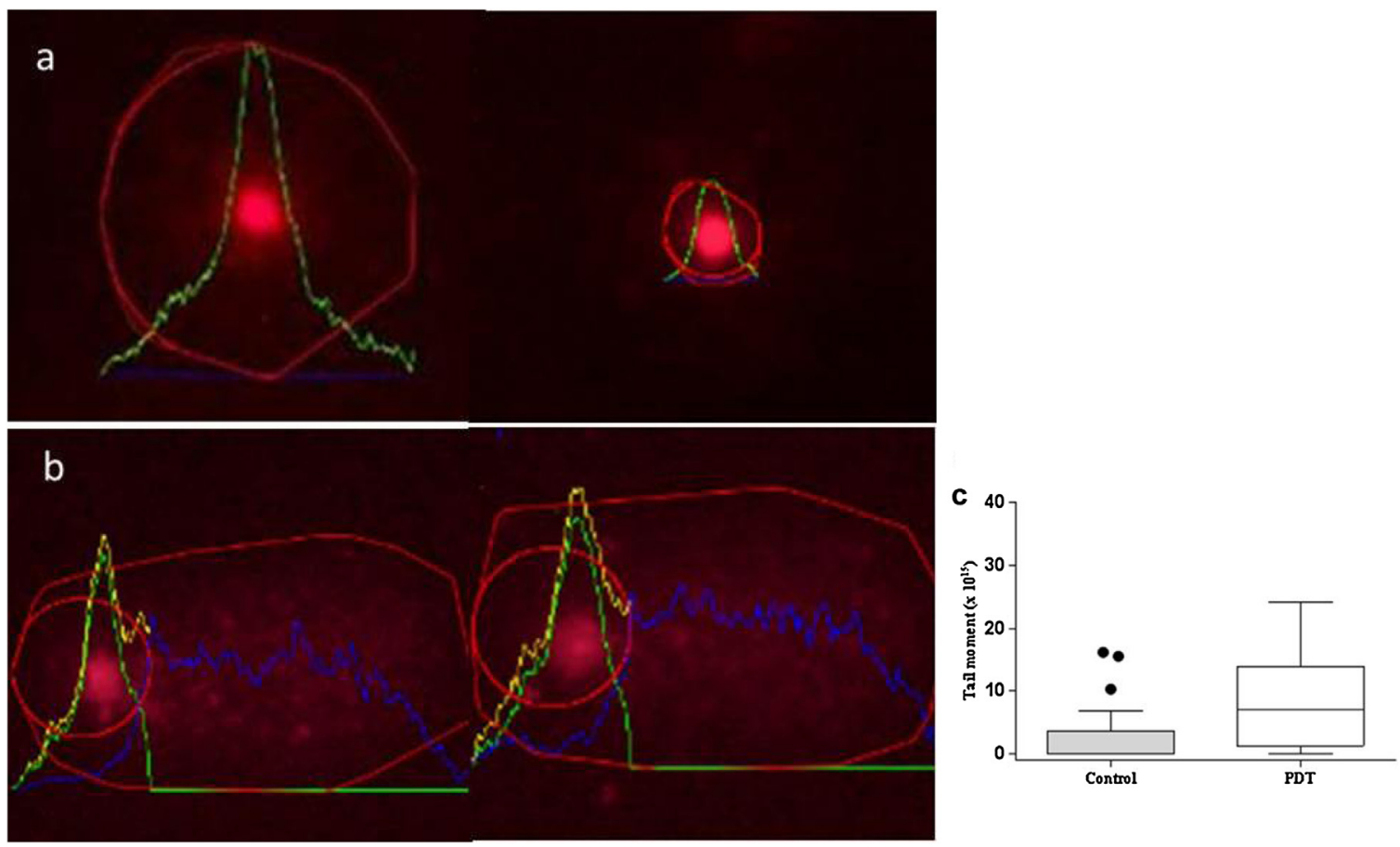

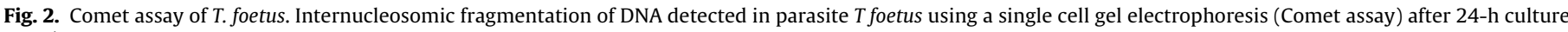

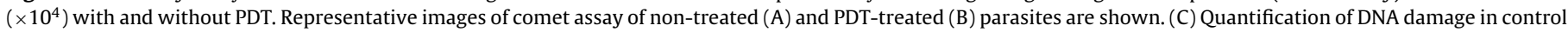
versus PDT-treated $T$. foetus; expressed as mean $( \pm \mathrm{SD})$ tail moment. $\mathrm{P}=0.0051$ ( $t$-testes). These results are the average of triplicate experiments.

\section{Discussion}

To provide subsidies for understanding the cell death mechanism in amitochondrial protozoan $T$. foetus after PDT, the present study presented the DNA fragmentation profiles with apoptotic features obtained by electrophoresis and comet assay analyses.

Trichomonad apoptotic cells do not show the same nuclear organization seen in mammals. After treatment with $\mathrm{H}_{2} \mathrm{O}_{2}$, some unusual chromatin condensation patterns and peripheral heterochromatin masses have been found in a large number of cells. In addition, DNA nuclear fragmentation was observed probably as a result of activation of different endonucleases during the death process [40]. The changes observed in DNA nuclear morphology in PDT-treated cells (Fig. 1) relates PDT performance to DNA fragmentation. Eukaryotic DNA wraps around an octamer of small basic proteins, called histones, to form the nucleosomes, the first chromatin package level; $146 \mathrm{bp}$ are wrapped around the histone core and the remaining bases link to the next nucleosome. Then, the nucleosomes are grouped to form a $30 \mathrm{~nm}$ fibre, which coils around each other to form a loop of approximately $50 \mathrm{~kb}$ followed by a rosette (consisting of six connected loops), then a coil, and, lastly, the chromatids. Detection of high molecular weight (HMW) DNA, $300 \mathrm{~kb}$, inside the nucleus indicates the cleavage of rosettes (six 50fold loops), which is often an early event in PCD. HMW DNA can be cleaved into $50 \mathrm{~kb}$ fragments and then into low molecular weight (LMW) fragments of 180-200 pb. The last cleavage occurs when an activated nuclease cleaves the DNA at linker sites between nucleosomes, resulting in fragments that are multimers of 180-200 bp [41]. The presence of LMW fragments is a typical picture of apoptosis in various cell systems [42-48]. It is important to mention that the DNA damage caused by PDT is related to the treatment dose, length, etc., and that the resulting DNA fragmentation does not necessarily lead to cell death. The cell death process depends on how the organism (or cell) responds to this damage, whether it is either able to repair it or a cell death mechanism is triggered $[2,49]$.
The ladder pattern formed by multiple $200 \mathrm{pb}$ bands observed in this study after the PDT treatment (Fig. 1B) is compatible with internucleosomal genome fragmentation, hence apoptosis [50,51]. Samples not treated with PDT presented a less evident ladder pattern (Fig. 1A). Although the formation of the DNA ladder is, in fact, the end point of DNA degradation and does not reflect the full DNA fragmentation pattern occurring during apoptosis, it is known that it is preceded by rosette cleavage and the $50-\mathrm{kb}$ rosette component, in turn, is preceded by the formation of HMW DNA fragments, which are considered to be the most reliable biochemical markers for initial apoptosis [48].

Despite the fact that a variety of techniques have emerged to detect apoptotic DNA fragmentation, the Single Cell Gel Electrophoresis (SCGE), or Comet assay, used in this study, is the method most widely applied for the detection of DNA damage in single cells [39]. The SCGE/Comet Assay, a sophisticated and precise method of cell death measurement at single cell level, has been validated and many different cell models use it as a convenient method of DNA damage and repair screening, anti-cancer agent toxicity and in apoptosis studies [52]. The Comet Assay technique was originally developed by [53] and modified for human blood cells by [37]. It is considered a relatively simple, rapid and sensitive technique to detect various sorts of DNA damage, including oxidative damage inflicted by ROS at single-cell level at a reasonably low cost [36,54-58]. This powerful technique facilitates the denaturation, unwinding, and detection of single strand breaks as well as DNA breaks by exposure to alkali [54]. It has been adapted for use with various eukaryotic cells, including animal, plant, yeast, algae [59-61], and protozoan (Tetrahymena thermophile) cells [62]. In cases of apoptotic cell death, the comet-like structures present large tails and small heads, defined as cells in which more than $90 \%$ of the nucleus DNA migrated to the tail $[48,63]$. Differently from viable cells, which display a large head with only a minute tail, and necrotic cells, which display large nuclear remnants and almost invisible tails [48]. After the PDT treatment of $T$. foetus, it 
was possible to observe that more nuclear DNA was fragmented and formed the comet tail characteristic of apoptosis (Fig. 2).

It was previously reported that PDT induces cell and hydrogenosome shape changes [34] and lysosomal enzyme release [64] in $T$. foetus. These structural changes, together with the data reported here, indicate that PDT may have induced PCD by apoptosis, autophagy or paraptosis, which was considered an alternative form of PCD by [65]. Other studies show that $\mathrm{H}_{2} \mathrm{O}_{2}$ also induces the same changes in T. foetus cells [34].

A form of cell death with features different from those described for necrosis was observed here; however, it resembled a PCD-like death with hallmarks of apoptosis, including DNA fragmentation. Studies have show that $T$. foetus shares this morphological feature with multicellular organisms [66,67]. Various forms of chromatin condensation during PCD found in unicellular and multicellular amitochondriate organisms were also observed in $T$. foetus here. In this study, the treated parasite showed a specific fragmentation pattern characteristic of apoptosis, producing DNA fragments of 180 nucleotides in length, known as characteristic oligonucleosomal fragmentation $[41,43,44,68-78]$. However, DNA molecular analysis of $T$. vaginalis showed no particular pattern of DNA fragmentation [79]. Thus, our data indicates the possible existence of a different DNA fragmentation mechanism for $T$. foetus that has already been described for T. vaginalis. Furthermore [80], some demonstrated aspects resembling apoptosis, such as nuclear fragmentation, chromatin condensation, phosphatidylserine exposure and transmembrane potential disruption, besides the possible presence of caspase-3, were activated during $\mathrm{H}_{2} \mathrm{O}_{2}$ treatment [34], and similar results were observed after treatment with a photosensitizer or PDT [28] in this trichomonad.

\section{Conclusion}

We demonstrate that PDT induces apoptosis in T. foetus, acting on DNA fragmentation, resulting in nuclear morphological alterations. As T. foetus is an amitochondrial protozoan, other organelles may be involved in the mechanism of cell death by apoptosis, suggesting new studies of metabolic pathways and molecules involved as effectors and suppressors of intermediates.

\section{Acknowledgement}

This work was supported by the Sao Paulo Research Foundation (grant number 2013/20054-8).

\section{References}

[1] B.N. Singh, J.J. Lucas, D.H. Beach, S.T. Shin, R.O. Gilbert, Adhesion of Tritrichomonas foetus to bovine vaginal epithelial cells, Infect. Immun. 67 (1999) 3847-3854.

[2] M.R.H. Pawel Mroz, Anastasia Yaroslavsky, Gitika B. Kharkwal, Cell death pathways in photodynamic therapy of cancer, Cancer (2011), http://dx.doi org/10.3390/cancers3022516.

[3] Terapia Fotodinâmica: Princípios, Potencial de Aplicação e Perspectivas, 23 (2000) 237-243.

[4] S.M. Machado, C. Pacheco-Soares, F.R. Marciano, A.O. Lobo, N.S. Da Silva, Photodynamic therapy in the cattle protozoan Tritrichomonas foetus cultivated on superhydrophilic carbon nanotube, Mater. Sci. Eng. C. 36 (2014) 180-186, http://dx.doi.org/10.1016/j.msec.2013.12.004.

[5] S.D.R.M. Ferreira, A.C. Tedesco, G. Sousa, R.A. Zângaro, N.S. Silva, M.T.T. Pacheco, et al., Analysis of mitochondria, endoplasmic reticulum and actin filaments after PDT with AlPcS(4), Lasers Med. Sci. 18 (2004) 207-212, http:// dx.doi.org/10.1007/s10103-003-0282-6.

[6] K.C. Ribeiro, R.M. Mariante, L.L. Coutinho, M. Benchimol, Nucleus behavior during the closed mitosis of Tritrichomonas foetus, Biol. Cell. 94 (2002) 289-301, http://dx.doi.org/10.1016/S0248-4900(02)01206-6.

[7] A.M. Rkein, D.M. Ozog, Photodynamic therapy, Dermatol. Clin. 32 (2014) 415-425, http://dx.doi.org/10.1016/j.det.2014.03.009.

[8] D. Kessel, R. Luguya, M.G.H. Vicente, Localization and photodynamic efficacy of two cationic porphyrins varying in charge distributions, Photochem.
Photobiol. 78 (2003) 431-435, http://dx.doi.org/10.1562/00318655(2003)0780431LAPEOT2.0.CO2.

[9] M. Tijerina, P. Kopecková, J. Kopecek, Mechanisms of cytotoxicity in human ovarian carcinoma cells exposed to free Mce6 or HPMA copolymer-Mce6 conjugates, Photochem. Photobiol. 77 (2003) 645-652, http://dx.doi.org/10. 1562/0031-8655(2003)077<0645:MOCIHO>2.0.CO;2.

[10] A. Feofanov, G. Sharonov, T. Karmakova, A. Pljutinskaya, V. Lebedeva, et al., Comparative Study 79 (2004) 172-188.

[11] P. Meier, A. Finch, G. Evan, Apoptosis in development, Nature 407 (2000) 796-801, http://dx.doi.org/10.1038/35037734.

[12] J.J. Lemasters, Dying a thousand deaths: redundant pathways from different organelles to apoptosis and necrosis, Gastroenterology 129 (2005) 351-360, http://dx.doi.org/10.1053/j.gastro.2005.06.006.

[13] C. Assunção Guimarães, R. Linden, Programmed cell deaths. Apoptosis and alternative deathstyles, Eur. J. Biochem. 271 (2004) 1638-1650, http://dx.doi org/10.1111/j.1432-1033.2004.04084.x.

[14] E. Candal, R. Anadón, W.J. Degrip, I. Rodríguez-Moldes, Patterns of cell proliferation and cell death in the developing retina and optic tectum of the brown trout, Dev. Brain Res. 154 (2005) 101-119, http://dx.doi.org/10.1016/j. devbrainres.2004.10.008.

[15] A. Vardi, I. Berman-Frank, T. Rozenberg, O. Hadas, A. Kaplan, A. Levine, Programmed cell death of the dinoflagellate Peridinium gatunense is mediated by CO2 limitation and oxidative stress, Curr. Biol. 9 (1999) 1061-1064, http://dx.doi.org/10.1016/S0960-9822(99)80459-X.

[16] S.B. Ning, H.L. Guo, L. Wang, Y.C. Song, Salt stress induces programmed cell death in prokaryotic organism Anabaena, J. Appl. Microbiol. 93 (2002) 15-28, http://dx.doi.org/10.1046/j.1365-2672.2002.01651.x.

[17] A. Debrabant, N. Lee, S. Bertholet, R. Duncan, H.L. Nakhasi, Programmed cell death in trypanosomatids and other unicellular organisms, Int. J. Parasitol. 33 (2003) 257-267, http://dx.doi.org/10.1016/S0020-7519(03)00008-0.

[18] M. Segovia, L. Haramaty, J. a Berges, P.G. Falkowski, Cell death in the unicellular chlorophyte Dunaliella tertiolecta. A hypothesis on the evolution of apoptosis in higher plants and metazoans, Plant Physiol. 132 (2003) 99-105, http://dx.doi.org/10.1104/pp.102.017129.

[19] I. Berman-Frank, K.D. Bidle, L. Haramaty, P.G. Falkowski, The demise of the marine cyanobacterium, Trichodesmium spp., via an autocatalyzed cell death pathway, Limnol. Oceanogr. 49 (2004) 997-1005, http://dx.doi.org/10.4319/ lo.2004.49.4.0997.

[20] K.D. Bidle, P.G. Falkowski, Cell death in planktonic, photosynthetic microorganisms, Nat. Rev. Microbiol. 2 (2004) 643-655, http://dx.doi.org/10. $1038 /$ nrmicro956.

[21] D.J. Franklin, J.A. Berges, Mortality in cultures of the dinoflagellate Amphidinium carterae during culture senescence and darkness, Proc. Biol. Sci. 271 (2004) 2099-2107, http://dx.doi.org/10.1098/rspb.2004.2810.

[22] R. Casotti, S. Mazza, C. Brunet, V. Vantrepotte, A. Ianora, A. Miralto, Growth inhibition and toxicity of the diatom aldehyde 2-trans, 4-trans-decadienal on Thalassiosira weissflogii (Bacillariophyceae), J. Phycol. 41 (2005) 7-20, http:// dx.doi.org/10.1111/j.1529-8817.2005.04052.x.

[23] P. Cuervo, N. Fernandes, J. Batista, D. Jesus, A proteomics view of programmed cell death mechanisms during host-parasite interactions, J. Proteomics. 75 (2011) 246-256, http://dx.doi.org/10.1016/j.jprot.2011.07.027.

[24] M. Deponte, Programmed cell death in protists, Biochim. Biophys. Acta 1783 (2008) 1396-1405, http://dx.doi.org/10.1016/j.bbamcr.2008.01.018.

[25] R.B. Giordani, P. De Brum Vieira, M. Weizenmann, D.B. Rosemberg, A.P. Souza, C. Bonorino, et al., Lycorine induces cell death in the amitochondriate parasite, Trichomonas vaginalis, via an alternative non-apoptotic death pathway, Phytochemistry 72 (2011) 645-650, http://dx.doi.org/10.1016/j. phytochem.2011.01.023.

[26] H. Zanin, A. Margraf-Ferreira, N.S. Da Silva, F.R. Marciano, E.J. Corat, A.O. Lobo, Graphene and carbon nanotube composite enabling a new prospective treatment for trichomoniasis disease, Mater. Sci. Eng. C 41 (2014) 65-69, http://dx.doi.org/10.1016/j.msec.2014.04.020.

[27] J. Kulda, Trichomonads, hydrogenosomes and drug resistance, Int. J. Parasitol. 29 (1999) 199-212, http://dx.doi.org/10.1016/S0020-7519(98)00155-6.

[28] N.S. da Silva, C.M. de Ribeiro, A.H.A. Machado, C. Pacheco-Soares, Ultrastructural changes in Tritrichomonas foetus after treatments with AlPcS4 and photodynamic therapy, Vet. Parasitol. 146 (2007) 175-181, http:// dx.doi.org/10.1016/j.vetpar.2007.02.006.

[29] R.M. Mariante, R.G. Vancini, M. Benchimol, Cell death in trichomonads: new insights, Histochem. Cell Biol. 125 (2006) 545-556, http://dx.doi.org/10.1007/ s00418-005-0098-5.

[30] R.F. Madeiro Da Costa, M. Benchimol, The effect of drugs on cell structure of Tritrichomonas foetus, Parasitol. Res. 92 (2004) 159-170, http://dx.doi.org/ 10.1007/s00436-003-1023-2.

[31] K.Y. Huang, F.M. Ku, W.H. Cheng, C.C. Lee, P.J. Huang, L.J. Chu, et al., Novel insights into the molecular events linking to cell death induced by tetracycline in the amitochondriate protozoan Trichomonas vaginalis, Antimicrob. Agents Chemother. 59 (2015) 6891-6903, http://dx.doi.org/10.1128/AAC.01779-15.

[32] A. Pereira-Neves, L. Gonzaga, R.F.S. Menna-Barreto, M. Benchimol, Characterisation of $20 \mathrm{~S}$ proteasome in tritrichomonas foetus and its role during the cell cycle and transformation into endoflagellar form, PLoS One 10 (2015) e0129165, http://dx.doi.org/10.1371/journal.pone.0129165.

[33] K.P. Carvalho, A.P.R. Gadelha, Effects of three benzimidazoles on growth, general morphology and ultrastructure of Tritrichomonas foetus, FEMS Microbiol. Lett. 275 (2007) 292-300, http://dx.doi.org/10.1111/j.1574-6968. 2007.00897.x. 
[34] R.M. Mariante, C.A. Guimares, R. Linden, M. Benchimol, Hydrogen peroxide induces caspase activation and programmed cell death in the amitochondrial Tritrichomonas foetus, Histochem. Cell Biol. 120 (2003) 129-141, http://dx. doi.org/10.1007/s00418-003-0548-x.

[35] M. Benchimol, Hydrogenosome autophagy: an ultrastructural and cytochemical study, Biol. Cell. 91 (1999) 165-174 http://www.ncbi.nlm.nih. gov/pubmed/10425703.

[36] I.C.S. Carvalho, T.P. Dutra, D.P. De Andrade, I. Balducci, C. Pacheco-Soares, R.F. da Rocha, High doses of alcohol during pregnancy cause DNA damages in osteoblasts of newborns rats, Birth Defects Res. Part A Clin. Mol. Teratol. 106 (2016) 122-132, http://dx.doi.org/10.1002/bdra.23468.

[37] N.P. Singh, M.T. McCoy, R.R. Tice, E.L. Schneider, A simple technique for quantitation of low levels of DNA damage in individual cells, Exp. Cell Res. 175 (1988) 184-191, http://dx.doi.org/10.1016/0014-4827(88)90265-0.

[38] B.M. Gyori, G. Venkatachalam, P.S. Thiagarajan, D. Hsu, M.V. Clement, OpenComet: an automated tool for comet assay image analysis, Redox Biol. 2 (2014) 457-465, http://dx.doi.org/10.1016/j.redox.2013.12.020.

[39] G.E. Winter, B. Radic, C. Mayor-Ruiz, V.A. Blomen, C. Trefzer, R.K. Kandasamy, et al., The solute carrier SLC35F2 enables YM155-mediated DNA damage toxicity, Nat. Chem. Biol. 10 (2014) 768-773, http://dx.doi.org/10.1038/ nchembio.1590.

[40] G. Motalleb, N. Sanadgol, J. Estakhr, E. Shahraki, Methods for DNA strand breaks detection, Res. J. Appl. Sci. Eng. Technol. 4 (2012) 1888-1894.

[41] M.J. Arends, R.G. Morris, A.H. Wyllie, Apoptosis. The role of the endonuclease, Am. J. Pathol. 136 (1990) 593-608 http://www.pubmedcentral.nih.gov/ articlerender.fcgi? artid=1877493\&tool=pmcentrez\&rendertype=abstract.

[42] T.J. Reape, P.F. McCabe, Apoptotic-like programmed cell death in plants, New Phytol. 180 (2008) 13-26, http://dx.doi.org/10.1111/j.1469-8137.2008.02549.

[43] J. Pollard, Techniques in molecular biology, FEBS Lett. 174 (1984) 185, http:// dx.doi.org/10.1016/0014-5793(84)81105-9.

[44] C.D. Bortner, B.E.N. Oldenburg, J.A. Cidlowski, N.B.E. Oldenburg, The role of DNA fragmentation in apoptosis, Trends Cell Biol. 5 (1995) 21-26, http://dx. doi.org/10.1016/S0962-8924(00)88932-1.

[45] R. Sgonc, J. Gruber, Apoptosis detection: an overview, Exp. Gerontol. 33 (1998) 525-533, http://dx.doi.org/10.1016/S0531-5565(98)00031-X.

[46] V.M.V. Martins, A.P. Marques, A.C. Vasconcelos, E. Martins, R.L. Santos, F.P.C Lima, Placental maturation and expulsion in Holstein and Nelore cows, Arq Bras. Med. Vet. E Zootec. 56 (2004) 157-167, http://dx.doi.org/10.1590 S0102-09352004000200004.

[47] J.J. Batista, A.S. Martins, L. Moro, A.C. Vasconcelos, Expressão gênica de caspases 3 e 8 em timo e baço de ratas recém-desmamadas imunossuprimidas por glicocorticóide, Arq. Bras. Med. Vet. E Zootec. 57 (2005) 457-464

[48] K.K.O.L. Meça, H.L.D. Del Puerto, L.V. Rodrigues, M.A. Rachid, N.B. Pereira, M.G.L. Cândido, et al., Apoptose na maturaçáo placentária de vacas em diferentes estágios de gestação: evidenciação imuno-histoquímica e bioquímica, Pesqui. Vet. Bras. 31 (2011) 718-722, http://dx.doi.org/10.1590/ S0100-736x2011000800015.

[49] K. Kumaraswamy, M. Archana, T. Bastian, Yogesh, Various methods available for detection of apoptotic cells-a review, Indian J. Cancer 50 (2013) 274, http://dx.doi.org/10.4103/0019-509X.118720.

[50] L.F. Agnez-lima, J.T.A. Melo, A.E. Silva, A.H.S. Oliveira, A.R.S. Timoteo, K.M Lima-bessa, et al., DNA damage by singlet oxygen and cellular protective mechanisms, Mutat. Res. 751 (2012) 15-28, http://dx.doi.org/10.1016/j mrrev.2011.12.005.

[51] R. Mittler, E. Lam, Sacrifice in the face of foes: pathogen-induced programmed cell death in plants, Trends Microbiol. 4 (1996) 10-15, http://dx.doi.org/10. 1016/0966-842X(96)81499-5.

[52] A. Danon, P. Gallois, UV-C radiation induces apoptotic-like changes in Arabidopsis thaliana, FEBS Lett. 437 (1998) 131-136, http://dx.doi.org/10. 1016/S0014-5793(98)01208-3.

[53] B.Y.T.K.K, M. Archana, Various methods available for detection of apoptotic cell-a review, Mutat. Res. 585 (2005) 71-78 http://www.ncbi.nlm.nih.gov/ pubmed/24061471.

[54] O. Ostling, K.J. Johanson, Microelectrophoretic study of radiation-induced DNA damages in individual mammalian cells, Biochem. Biophys. Res. Commun. 123 (1984) 291-298, http://dx.doi.org/10.1016/0006-291X(84)90411-X.

[55] D.W. Fairbairn, P.L. Olive, K.L. O'Neill, The comet assay: a comprehensive review, Mutat. Res. 339 (1995) 37-59, http://dx.doi.org/10.1016/01651110(94)00013-3.

[56] J. Da Silva, T.R.O. De Freitas, J.R. Marinho, G. Speit, B. Erdtmann, An alkaline single-cell gel electrophoresis (comet) assay for environmental biomonitoring with native rodents, Genet. Mol. Biol. 23 (2000) 241-245, http://dx.doi.org/ 10.1590/S1415-47572000000100042.

[57] P. Grover, K. Danadevi, M. Mahboob, R. Rozati, B.S. Banu, M.F. Rahman, et al., Evaluation of genetic damage in workers employed in pesticide production utilizing the Comet assay resulting in the need for increased production of pesticides. potential carcinogens. Therefore, in the current study pesticides of Indian pesticide produ, Mutagenesis 18 (2003) 201-205

[58] A.R. Collins, Measuring oxidative damage to DNA and its repair with the comet assay, BBA-Gen. Subj. 2014 (1840) 794-800, http://dx.doi.org/10. 1016/j.bbagen.2013.04.022.
[59] A.M. Moro, N. Brucker, M. Charão, R. Bulcão, F. Freitas, M. Baierle, et al. Evaluation of genotoxicity and oxidative damage in painters exposed to low levels of toluene, Mutat. Res.-Genet. Toxicol. Environ. Mutagen. 746 (2012) 42-48, http://dx.doi.org/10.1016/j.mrgentox.2012.02.007.

[60] M. Erbes, M. Erbes, A. Webler, A. We, U. Obst, U. Obst, et al., Detection of primary DNA damage, Environ. Mol. Mutagen. 458 (1997) 448-458.

[61] O. Ptacek, D.A. Stavreva, J.K. Kim, T. Gichner, Induction and repair of DNA damage as measured by the Comet assay and the yield of somatic mutations in gamma-irradiated tobacco seedlings, Mutat. Res.-Genet. Toxicol. Environ. Mutagen. 491 (2001) 17-23, http://dx.doi.org/10.1016/S13835718(00)00146-7.

[62] E. Rojas, M.C. Lopez, M. Valverde, Single cell gel electrophoresis assay: methodology and applications, J. Chromatogr. B 722 (1999) 225-254, http:// dx.doi.org/10.1016/S0378-4347(98)00313-2.

[63] B. Lah, S. Malovrh, M. Narat, T. Cepeljnik, R. Marinsek-Logar, Detection and quantification of genotoxicity in wastewater-treated Tetrahymena thermophila using the comet assay, Environ. Toxicol. 19 (2004) 545-553, http://dx.doi.org/10.1002/tox.20062.

[64] a K. Haylett, T.H. Ward, J.V. Moore, DNA damage and repair in Gorlin syndrome and normal fibroblasts after aminolevulinic acid photodynamic therapy: a comet assay study, Photochem. Photobiol. 78 (2003) 337-341, http://dx.doi.org/10.1562/0031-8655(2003)078<0337:DDARIG>2.0.CO;2.

[65] S.M. Machado, C. Pacheco-Soares, F.R. Marciano, A.O. Lobo, N.S. da Silva, Photodynamic therapy in the cattle protozoan Tritrichomonas foetus cultivated on superhydrophilic carbon nanotube, Mater. Sci. Eng. C. Mater. Biol. Appl. 36 (2014) 180-186, http://dx.doi.org/10.1016/j.msec.2013.12.004.

[66] S. Sperandio, I. de Belle, D.E. Bredesen, An alternative, nonapoptotic form of programmed cell death, Proc. Natl. Acad. Sci. 97 (2000) 14376-14381, http:// dx.doi.org/10.1073/pnas.97.26.14376.

[67] S. Kaczanowski, M. Sajid, S.E. Reece, Evolution of apoptosis-like programmed cell death in unicellular protozoan parasites, Parasite Vectors 4 (2011) 44, http://dx.doi.org/10.1186/1756-3305-4-44.

[68] P.M. Durand, R. Choudhury, A. Rashidi, R.E. Michod, P.M. Durand, Programmed death in a unicellular organism has species-specific fitness effects, Biol. Lett. (2014) 8-11.

[69] Y.A. Ioannou, F.W. Chen, Quantitation of DNA fragmentation in apoptosis, Nucleic Acids Res. 24 (1996) 992-993

[70] A.K. Bissenbaev, A.A. Ishchenko, S.M. Taipakova, M.K. Saparbaev, Plant Physiology and Biochemistry Presence of base excision repair enzymes in the wheat aleurone and their activation in cells undergoing programmed cell death, Plant Physiol. Biochem. 49 (2011) 1155-1164, http://dx.doi.org/10. 1016/j.plaphy.2011.07.017.

[71] G.M. Cohen, X. Sun, R.T. Snowden, D. Dinsdale, D.N. Skilleter, Key morphological features of apoptosis may of internucleosomal DNA fragmentation the absence, Biochem. J. 286 (1992) 331-334.

[72] J. Gong, F. Traganos, Z. Darzynkiewicz, A selective procedure for DNA extraction from apoptotic celss aplicable for Gel Electrophoresis and Flow cytometry, Anal. Biochem. (1994), http://dx.doi.org/10.1006/abio.1994.1184.

[73] V. Iglesias-guimarais, E. Gil-guiñon, G. Gabernet, M. García-belinchón, M. Sánchez-osuna, E. Casanelles, et al., Apoptotic DNA degradation into oligonucleosomal fragments, but not apoptotic nuclear morphology, relies on a cytosolic pool of DFF40/CAD endonuclease, J. Biol. Chem. 287 (2012) 7766-7779, http://dx.doi.org/10.1074/jbc.M111.290718.

[74] P.R. Walker, J. Leblanc, B. Smith, S. Pandey, M. Sikorska, Detection of DNA fragmentation and endonucleases in apoptosis, Methods 17 (1999) 329-338, http://dx.doi.org/10.1006/meth.1999.0747.

[75] S. Moharikar, J.S. D\&apos;Souza, A.B. Kulkarni, B.J. Rao, Apoptotic-like cell death pathway is induced in unicellular chlorophyte Chlamydomonas reinhardtii (Chlorophyceae) cells following UV irradiation: detection and functional analyses, J. Phycol. 42 (2006) 423-433, http://dx.doi.org/10.1111/j. 1529-8817.2006.00207.x.

[76] P.S. Gullicksen, R.G. Dean, C.A. Baile, Detection of DNA fragmentation and apoptotic proteins, and quantification of uncoupling protein expression by real-time RT-PCR in adipose tissue, J. Biochem. Biophys. Methods. 58 (2004) 1-13, http://dx.doi.org/10.1016/S0165-022X(03)00151-9.

[77] Y. Otsuki, Z. Li, M. Shibata, Apoptotic detection methods-from morphology to gene yoshinori otsuki zhonglian Li masa-Aki shibata, Prog. Histochem. 38 (2003) 275-340

[78] P.T. Daniel, I. Sturm, S. Ritschel, K. Friedrich, B. Dörken, P. Bendzko, et al., Detection of genomic DNA fragmentation during apoptosis (DNA ladder) and the simultaneous isolation of RNA from low cell numbers, Anal. Biochem. 266 (1999) 110-115, http://dx.doi.org/10.1006/abio.1998.2929.

[79] A.M.A. Nasirudeen, Y.E. Hian, M. Singh, K.S.W. Tan, Metronidazole induces programmed cell death in the protozoan parasite Blastocystis hominis, Microbiology 150 (2004) 33-43, http://dx.doi.org/10.1099/mic.0.26496-0.

[80] I.V. Shemarova, Comparative Biochemistry and Physiology, Part B Signaling mechanisms of apoptosis-like programmed cell death in unicellular eukaryotes, Comp. Biochem. Physiol. Part B 155 (2010) 341-353, http://dx doi.org/10.1016/j.cbpb.2010.01.010. 